\title{
TURYSTYKA JAKO DYSCYPLINA NAUKOWA - DYLEMATY TEORETYCZNE VERSUS RZECZYWISTOŚĆ EMPIRYCZNA
}

\section{Wprowadzenie}

Analizując problem nadania turystyce statusu samodzielnej dyscypliny naukowej można zauważyć wiele zróżnicowanych i często przeciwstawnych opinii artykułowanych przez różne grupy naukowców. Wydaje się, że wynikają one $w$ dużym stopniu $\mathrm{z}$ różnych tradycji badawczych (wraz z uznawanymi w ich obrębie paradygmatami), z których wywodzą się poszczególni badacze turystyki. Oznacza to, że być może kluczową rolę odgrywa tutaj tzw. tożsamość naukowa badaczy (KADRI 2008), która wpływa na ich poglądy odnośnie do statusu turystyki jako dyscypliny naukowej.

Wydaje się jednak, że punktem wyjścia szczegółowych analiz powinno być przyjęcie szerszej perspektywy poznawczej określonej w zasadniczym pytaniu, czy będziemy w stanie lepiej poznawać turystykę dysponując samodzielną dyscypliną naukową, czy też powinniśmy poprzestać na jej badaniu wykorzystując dorobek dyscyplin już istniejących? Innymi słowy, można by zapytać czy nasza wiedza o turystyce będzie bogatsza dzięki powstaniu nowej dyscypliny? Biorąc pod uwagę tak szerokie pole badawcze turystyki (a tym samym obszary zainteresowań badaczy) konkluzja nie wydaje się być oczywista i zależy od odpowiedzi na następujące pytania szczególowe: 1) czy jest możliwa naukowa specjalizacja w tak szerokiej dziedzinie jaka odnosi się do turystyki?, 2) czy w obrębie jednej dyscypliny możliwe będzie 
rozwiązywanie (ale również kreowanie) tak różnorodnych problemów badawczych?, 3) czy istnieją problemy naukowe, które będzie łatwiej rozwiązać wykorzystując dorobek jednej dyscypliny?

Zarówno tożsamość naukowa badaczy turystyki, jak również problem funkcjonalności nowej dyscypliny jako swoistego instrumentarium poznawczego turystyki stanowily przedmiot dociekań $\mathrm{w}$ badaniach ankietowych przeprowadzonych wśród badaczy turystyki z kilkudziesięciu krajów świata. Wyniki tych badań zostały skonfrontowane $\mathrm{z}$ poglądami prezentowanymi w literaturze angielskojęzycznej, francuskojęzycznej oraz polskiej. Dało to podstawę do sformułowania końcowych wniosków stanowiących próbę odpowiedzi na postawione pytania badawcze. Przy czym jako podstawę teoretyczną wykorzystano pewne założenia pochodzące $\mathrm{z}$ dorobku tzw. nieklasycznej socjologii nauki (non-classical sociology of science).

\section{Przegląd literatury}

Można przyjąć, że problem turystyki jako obszaru badań oraz turystyki jako samodzielnej dyscypliny naukowej pojawił się w literaturze przedmiotu prawie w tym samym okresie, kiedy zaczęła się dyskusja naukowa nad turystyką. Przy czym z większym natężeniem problematyka ta jest obecna przynajmniej od czterech dekad (AIREY 2008, BORRET 2005, KADRI 2008). W ostatnich latach $\mathrm{w}$ czasopismach o zasięgu międzynarodowym pojawiło się kilka tekstów przeglądowych poświęconych problematyce turystyki jako dyscypliny naukowej (BABU 2008, BUTOWSKI 2011, 2014c, red., CERIANI-SEBREGONDI i in. 2008, DARBELLAY, STOCK 2012, ECHTNER, JAMAL 1997, HILlaLi 2008, TAILLON 2014, RATZ 2014). Jednakże, mimo dość ożywionej dyskusji problem ten wydaje się być wciąż daleki od końcowych konkluzji. Przy czym tezę taką można postawić zarówno po analizie pozycji angielskojęzycznych, jak i francuskojęzycznych (RITCHIE, SHEENAN, TIMUR 2008, KADRI 2008). Jednocześnie dostrzec można trzy odrębne stanowiska prezentowane przez różne grupy badaczy, z których jedni są za uznaniem turystyki jako samodzielnej dyscypliny, inni przeciwko takiemu uznaniu, występuje także grupa badaczy niezdecydowanych pod tym względem.

Zwolennicy nauki o turystyce jako dyscypliny tacy, jak m.in.: S.S. BABU (2008), C.R. GOELDNER, J.R.B. RITCHIE (2006), Z. JOVICIC (1988), N. LEIPER (1981, 1990, 2000), S.J. PAGE (2003), C. RYAN (1997, 2001), P. ViCÉRIAT, C. ORIGET DU CLUZEAU i M. BALFET (2005), podnoszą różne argumenty wskazujące na 
potrzebę uznania turystyki za osobną dyscyplinę. Niektórzy z nich proponowali nawet nazwy dla takiej dyscypliny, np. "tourology” (LEIPER 1981), "tourismology" (JOVICIC 1988) czy „turystologia” (CHŁOPECKI 2005). J. STAFFORD (1985), sugerując termin téorologie, określił również cztery paradygmaty (nominalistyczny, ekonomiczno-przestrzenny, kulturowy i normatywny), które powinny stanowić podstawę, a jednocześnie pole badań nowej dyscypliny. Ten sam autor (STAFFORD 1992) wyraził nadzieję, że tak określone pole badawcze mogłoby zintegrować wiele elementów pochodzących z różnych dyscyplin. J.M. HOERNER (2000, 2002, 2008) oraz J.M. HOERNER, C. SICCART (2003) postulują uznanie tourismologie jako multidyscyplinarnej, humanistycznej i jednocześnie stosowanej nauki o syntetycznym charakterze, której przedmiotem badań miałaby być podróż (w różnych aspektach). Podobnie Z. JOVICIC (1988, s. 3) wzywa do uznania tourismology jako osobnej dyscypliny, która mogłaby syntetyzować fragmentaryczne badania nad turystyką. Zauważa on, że „badanie pojedynczych elementów w oderwaniu od całości zaowocowało błędnym postrzeganiem turystyki jako zjawiska ekonomicznego, geograficznego, czy socjologicznego". Część badaczy (COHEN 1979, COMIC 1989, ROGOZIŃSKI 1985) zgadza się z takimi opiniami, wskazując na to, że badania nad turystyką będą "cierpieć" z powodu braku pogłębionej analizy tak długo, jak pozostaną one rozdrobnione między różnymi dyscyplinami. Uważają oni jednocześnie, że do poważnej analizy teoretycznej niezbędna jest integracja badań nad turystyką (dotychczas prowadzonych z perspektywy równych dyscyplin). W podobnym kontekście J.R.B. RITCHIE, L.R. SHEEHAN i S. TIMUR (2008) proponują „,core-foundation model”, który pozwala na rozróżnienie hipotetycznej (hipotetycznych) teorii turystyki i teorii dyscyplin źródłowych (np. socjologicznych, geograficznych, ekonomicznych). Jeszcze dalej posuwa się L. MAZURKIEWICZ (2005, 2012), próbując dowieść za pomocą analizy formalnej, że turystyka zgromadziła już wystarczającą ilość własnej teorii. Duży wkład w stworzenie teoretycznych podstaw badań nad turystyką wniosła także, działająca od lat 90. XX w. grupa MIT - Mobility, Itinerary, Tourism (CERIANI-SEBREGONDI i in. 2008).

N. Leiper, jako jeden z głównych orędowników uznania turystyki jako dyscypliny naukowej, zwraca szczególną uwagę na społeczną akceptację tej dziedziny, a także jej gospodarcze i kulturowe znaczenie. Wyrazem tego są programy studiów akademickich (w niektórych krajach, takich jak: Australia, Kanada, Francja, Indie, Polska, Wielka Brytania, Stany Zjednoczone, przynajmniej od lat 70. ubiegłego wieku) oraz towarzyszące im programy badawcze. Podobne poglądy, chociaż wyrażane w nieco innych kontekstach, 
można zauważyć u takich badaczy, jak: J.R.B. RITCHIE, L.R. SHEEHAN i S. TIMUR (2008) czy M. HALL, A. WILLIAMS i A. LEW (2004). Nawet J. TRIBE (1997, 2003), który pomimo stanowczej krytyki uznania nauki o turystyce jako osobnej dyscypliny, proponuje rozdzielenie na potrzeby programów akademickich związanych z turystyką (,,body of tourism") między Tourism Business Studies a Tourism Development Studies (BABU 2008, s. 41). Z kolei inni autorzy, tacy jak R. BARNETT $(1990,1997)$ czy V. CUFFY, J. TRIBE i D. AIREY (2012), twierdzą, że w krajach, w których istnieje ugruntowana tradycja nauczania turystyki na poziomie akademickim, coraz bardziej cenione są kompetencje abstrakcyjne i umiejętność krytycznego myślenia.

$\mathrm{Z}$ drugiej strony istnieje liczna grupa przeciwników turystyki jako samodzielnej dyscypliny. W celu uzasadnienia swojego stanowiska używają oni głównie argumentów metodologicznych. I tak m.in. T. BOWEDES (1982), A. BORRET (2005), P.L. PEARCE (1993) i J. TRIBE (1997) stwierdzają, że turystyka nie ma jednej powszechnie akceptowanej definicji ani własnych, oryginalnych teorii - co stanowi najpoważniejszy zarzut $\mathrm{z}$ ontologicznego i epistemologicznego punktu widzenia. Nawet C.R. GOELDNER i J.R.B. RITCHIE (2006), którzy kwalifikują turystykę jako jedną z subdyscyplin w grupie nauk o zarządzaniu, przyznają, że brak definicji stanowi jeden $\mathrm{z}$ poważniejszych problemów. S. WITT, M. BROKE i P. BUCKLEY (1991, s. 164) dodają, że badania nad turystyką "pozostaną dynamiczne, zróżnicowane, a czasami wewnętrznie sprzeczne”. A. FRANKLIN i M. CRANG (2001), analizując sposób poszerzania wiedzy na temat turystyki zauważają, że badacze często ulegają wpływom politycznym lub są uzależnieni od instytucji finansujących badania. P. LYNCH i R. BROWN (1999), dodają, że dla czynników politycznych i biznesowych teoria stanowi zbędny balast, który nie ma większej wartości w kontekście praktycznych kwestii zarządzania turystyką. A. ATHIYAMAN (1997) krytykuje wielu badaczy turystyki za brak wkładu z ich strony w rozwój wiedzy teoretycznej. K. MEETHAN (2001, s. 2) krytycznie ocenia treść czasopism, książek i konferencji naukowych, które „pozostają niesteoretyzowane, eklektyczne i niekompatybilne". Podobnego zdania jest B. WEILER (2003), odrzucając pogląd J. Jafari jakoby badaniom nad turystyką nie można już zarzucić, że nie mają podstaw teoretycznych. H. Baretje (cyt. za KNAFOU 2005) stanowczo stwierdza, że turystyka nie jest i nigdy nie będzie nauką, a jedynie formą ludzkiej aktywności. Kolejne argumenty przeciwko uznaniu turystyki jako dyscypliny przytacza J. TRIBE (2006), opierając się na klasycznych pracach T.S. KUHNA (1996) dotyczących paradygmatu naukowego. Autor ten przywołuje wprowadzone przez Kuhna pojęcie „nauka 
normalna", które odnosi się do dojrzałych dyscyplin z ustalonymi paradygmatami. J. TRIBE (2006) stwierdza, że badania nad turystyką nie są prowadzonew ramach nauki normalnej, ponieważ znajdują się one co najwyżej w stadium przedparadygmatycznym. Ponadto C.M. ECHTNER i T.B. JAMAL (1997), opierając na modelu Kuhna, dodają, że badania nad turystyką prawdopodobnie pozostaną $\mathrm{w}$ stadium przedparadygmatycznym $\mathrm{w}$ związku z wzajemną nieprzystawalnością (incommensurability) różnych paradygmatów, w ramach których są prowadzone.

Poza wymienionymi argumentami przeciwko turystyce jako samodzielnej dyscyplinie, istnieje jeszcze jeden - podnoszony przez J. TRIBE'A (2006, s. 366) w jego znanej pracy dotyczącej prawdy o turystyce. Autor stwierdza, że „dyscypliny mogą odgrywać rolę selekcyjną, określając to, czego powinny dotyczyć badania (a czego nie)". W tym kontekście J. Tribe, bazując na pracach S. ARONOWITZA i H. GIROUX (1991), przywołuje problem „tyranizującej roli" dyscypliny, która mogłaby prowadzić do osłabienia badań nad turystyką zamiast je wzmacniać. Aby zilustrować ten pogląd autor ten wymienia prace C. ROJEK i J. URRY (1997) oraz A. FRANKLINA i M. CRANGA (2001), w których autorzy wskazują na tyranizującą rolę ekonomii w badaniu turystyki.

Pomiędzy omówionymi wcześniej poglądami zwolenników i oponentów turystyki jako nauki można wyróżnić grupę badaczy, którzy nie artykułują swoich poglądów tak jednoznacznie, chociaż dostrzegają wagę problemu. Zaliczyć do nich można m.in. I. ATELJEVICA, A. PrITCHARDA i N. MORGANA (2007), S.S. BABU (2008), G. CAZESA (2001), G. DANNA, D. NASHA i P. PEARCE' A (1988), J. JAFARI (1990, 2001) czy R. KNAFOU (2005). Zgadzają się oni, że turystyka może być traktowana jako obszar badań i są gotowi zaakceptować stwierdzenie, że badania na turystyką są w trakcie uzyskiwania dojrzałości. Pogląd taki dość dobrze wpisuje się we wcześniej wspomniany model Kuhna - a dokładnie jego fazę przedparadygmatyczną, w której przyszła dyscyplina wykorzystuje paradygmaty obowiązujące w innych dyscyplinach (SZUBERT-ZARZECZNY 2001). C.M. ECHTNER I T.B. JAMAL (1997, s. 876), pozostając raczej sceptyczni co do możliwości wykorzystania paradygmatycznego modelu Kuhna jako teoretycznej podstawy uznania nauki o turystyce, przyznają, że nie można wykluczyć możliwości wystąpienia określonej przez Kuhna rewolucji naukowej, ,w której grupa badaczy wyłamuje się z barier dyscyplinarnych i zaczyna pracę nad osobną dyscyplinarną matrycą dla badań nad turystyką". W tym kontekście nie chodzi jedynie o to, czy badania nad turystyką mogą zostać uznane za osobną dyscyplinę, ale także kiedy to miałoby nastąpić. Wydaje się, że jednym z najważniejszych 
zwolenników takiej opinii jest J. JAFARI (1990, 2001), który określa cztery platformy rozwoju badań nad turystyką i wskazuje, że platforma oparta na wiedzy jest chronologicznie najpóźniejsza i najbardziej aktualna. Ten sam autor w odniesieniu do turystyki stwierdza, że ,jej naukowa podróż w kierunku nowych granic, nowych horyzontów oczywiście trwa" (za BABU 2008, s. 39). Dość optymistyczną perspektywę przyjmują także C.M. ECHTNER i T.B. JAMAL (1997, s. 878), kiedy sugerują (w opozycji do paradygmatycznego modelu Kuhna) skorzystanie z podejścia R. BERNSTEINA (1991) dotyczącego metodologicznych współzależności między naukami przyrodniczymi (Naturwissenschaften) i społecznymi (Geisteswissenschaften).

W dyskusji na temat turystyki jako samodzielnej dyscypliny naukowej, poza omówionymi powyżej trzema głównymi stanowiskami, należy wymienić jeszcze jedną grupę badaczy, którzy widzą studia nad turystyką przede wszystkim jako domenę badań interdyscyplinarnych. Do autorów podzielających w dużym stopniu taki pogląd zaliczyć można m.in.: S. LISZEWSKIEGO (2010), P.L. PeARCE'A i R. Butlera (1993), J. TRIBE'A (2006) oraz S. WiTTA, M. BROKE i P. BUCKLEY'A (1991). Część z nich uważa, że podejście interdyscyplinarne $\mathrm{w}$ badaniach nad turystyka jest zgodne $\mathrm{z}$ postmodernistycznym apelem o hybrydyzację i postdyscyplinarność w nauce. Zwolennicy takiego poglądu zakładają, że interdyscyplinarność w badaniach nad turystyką będzie w stanie lepiej odpowiedzieć na potrzebę kreatywności i innowacji. B. KADRI (2008) uważa, że interdyscyplinarność pozwoliłaby badaniom nad turystyką zmniejszyć metodologiczne opóźnienie względem tradycyjnych dyscyplin. J.M. DeWAILly $(2006,2008)$, pozostając sceptycznym w odniesieniu do tourismologie Hoernera, sugeruje transdyscyplinarność w badaniach nad turystyką i proponuje paradygmat "federacyjny", który mógłby objać odmienne antropologiczne, geograficzne i historyczne aspekty i stworzyć $\mathrm{z}$ nich bazę nowej nauki. Dla niektórych badaczy nawet podejścia inter-, trans- i multidyscyplinarne nie są już zadowalające. COLES, HALL i DUVALL (2005, s. 31) utrzymują, że jeżeli badania nad turystyką mają odzwierciedlać współczesne warunki, „powinny odejść od tradycyjnych podejść w kierunku bardziej elastycznych form wytwarzania wiedzy". Ci sami autorzy (2005, s. 39) namawiają do „hybrydowego podejścia” w badaniach nad turystyką.

Przedstawiona dyskusja problemu w angielskojęzycznej i francuskojęzycznej literaturze przedmiotu miała za zadanie przybliżyć główne grupy poglądów na temat "dyscyplinarności” turystyki. W tym sensie miała ona również charakter wprowadzający do omówienia wyników badań empirycznych i dalszej dyskusji podsumowującej. Z drugiej strony wydaje się, że 
na przestrzeni ostatnich kilku lat wymiana poglądów na ten temat osłabła. Można nawet zaryzykować tezę, że przeciwnicy i zwolennicy turystyki jako osobnej dyscypliny trwają przy swoim i żadna strona nie jest gotowa na ustępstwa. Te okoliczności i widoczna niemożność osiągnięcia porozumienia skłoniły autora niniejszej pracy do zaproponowania nowego podejścia, które być może przybliżyłoby do osiągnięcia pewnego kompromisu.

\section{Turystyka jako dyscyplina naukowa w świetle badań empirycznych}

Badania empiryczne nad turystyką jako dyscypliną naukową objęły takie zagadnienia, jak: metodologiczne związki badaczy turystyki z ich macierzystymi dyscyplinami, ich samoidentyfikację jako przedstawicieli badań nad turystyką lub dyscyplin macierzystych, czy wreszcie przywiązanie badaczy turystyki do lokalnych paradygmatów poszczególnych dyscyplin (oraz ich gotowość do poszukiwania nowego paradygmatu "nauki o turystyce”).

\subsection{Metoda badawcza}

W badaniach zastosowano schemat trzyetapowy: 1) w pierwszej części dokonano przeglądu literatury przedmiotu (głównie angielskojęzycznej i francuskojęzycznej oraz pozycji polskich); 2) w dalszej kolejności przeprowadzono badania ankietowe obejmujące celową grupę respondentów; 3) na trzecim etapie skonfrontowano wnioski płynące z badań literatury z wynikami badań empirycznych.

Próba celowa objęła dwie grupy respondentów - zagranicznych badaczy turystyki oraz polskich naukowców zajmujących się tą dziedziną. Wśród respondentów zagranicznych znalazło się około 180 badaczy turystyki posiadających różny dorobek naukowy, w tym: profesorowie $20 \%$, doktorzy habilitowani $17 \%$, doktorzy 39\%, magistrowie $24 \%$. Reprezentowali oni różne publiczne i prywatne instytucje naukowe (głównie uniwersytety, ale również stowarzyszenia naukowe oraz inne ośrodki badawcze) z blisko 50 krajów na wszystkich kontynentach (tab. 1). Polska grupa objęła 89 badaczy z głównych ośrodków akademickich. Ze względu na wielkość próby krajowej (w porównaniu z liczebnością grupy międzynarodowej), nie została ona uwzględniona $w$ analizach ogólnych, a jedynie w analizach regionalnych obok pozostałych regionów. 
Tab. 1. Respondenci według kontynentów i państw

\begin{tabular}{|l|c|l|c|}
\hline \multicolumn{1}{|c|}{ Kontynent } & \multicolumn{1}{|c|}{$\begin{array}{c}\text { Liczba } \\
\text { respondentów }\end{array}$} & \multicolumn{1}{c|}{ Państwo/ region } & $\begin{array}{c}\text { Liczba } \\
\text { respondentów }\end{array}$ \\
\hline Afryka & 5 & RPA & 4 \\
\hline Azja & 12 & Chiny, Indie i Japonia & 6 \\
\hline Australia i Oceania & 7 & Australia i Nowa Zelandia & 7 \\
\hline Europa & 126 & $\begin{array}{l}\text { Austria, Niemcy } \\
\text { i Szwajcaria }\end{array}$ & 20 \\
\cline { 3 - 4 } & & Belgia i Holandia & 8 \\
\cline { 3 - 4 } & & $\begin{array}{l}\text { Srodkowa i Wschodnia } \\
\text { Europa (bez Polski) }\end{array}$ & 17 \\
\cline { 3 - 4 } & & Francja & 13 \\
\cline { 3 - 5 } & & Skandynawia & 24 \\
\cline { 3 - 5 } & & Europa Południowa & 31 \\
\cline { 3 - 5 } & & Wielka Brytania & 13 \\
\hline Północna i Południowa Ameryka & 23 & USA i Kanada & 20 \\
\hline Brak danych & \multirow{2}{*}{8} & $\begin{array}{l}\text { Inne kraje } \\
\text { Polska }\end{array}$ \\
\hline
\end{tabular}

Źródło: opracowanie własne.

Respondenci reprezentowali różne dyscypliny, takie jak: geografia, ekonomia, zarządzanie i marketing, studia regionalne, kultura fizyczna, sport i rekreacja, socjologia i antropologia oraz inne nauki społeczne i humanistyczne. Spośród wszystkich ankietowanych 73\% osób zadeklarowało, że badania nad turystyką stanowią dla nich główny obszar aktywności naukowej, zaś dla $27 \%$ turystyka jest dodatkową dziedziną badań. Badania ankietowe w grupie "międzynarodowej” przeprowadzono od kwietnia do listopada 2014 r., zaś w grupie "polskiej” od czerwca do grudnia 2013 r. Kwestionariusz składał się głównie z pytań zamkniętych dotyczących tożsamości naukowej badaczy oraz statusu metodologicznego (i formalnego) badań nad turystyką. Dodatkowo respondenci byli proszeni o uzasadnienie swoich opinii w formie swobodnej pisemnej wypowiedzi.

\subsection{Wyniki ogólne}

Wyniki badań przeprowadzonych wśród respondentów zagranicznych umożliwiają sformułowanie następujących wniosków o ogólnym charakterze: 1) niewielka większość $(50 \%)$ ankietowanych osób stwierdziła, że prowadzi badania nad turystyką korzystając $z$ paradygmatów uznanych przez „tradycyjne” dyscypliny naukowe; jednocześnie $45 \%$ uważało, że opiera się 
na oryginalnych paradygmatach przyjętych na potrzeby badan nad turystyką; 2) znacząca większość respondentów (59\%) uznało siebie za przedstawicieli studiów nad turystyką, podczas gdy 39\% czuło się bardziej reprezentantami "tradycyjnych" dyscyplin; 3) 53\% respondentów było skłonnych uznać naukę o turystyce jako nową dyscyplinę naukową; $36 \%$ było przeciwnego zdania. Ogólne wyniki analizy wskazują na pewną niekonsekwencję w opiniach respondentów "międzynarodowych" dotyczącą pozycji metodologicznej i formalnego statusu nauki o turystyce. $Z$ jednej strony są oni w większości gotowi traktować siebie za reprezentantów nauki o turystyce i dość łatwo opowiadają się za przyznaniem jej statusu nowej dyscypliny. $Z$ drugiej strony duża grupa respondentów pozostaje przywiązana do paradygmatów będących dorobkiem nauk "tradycyjnych".

Bardziej szczegółowa analiza opinii sformułowanych przez badaczy z tej grupy pozwala jednak na wskazanie kilku interesujących zależności o relatywnym charakterze. Osoby, które uzyskały wykształcenie w takich dyscyplinach, jak: ekonomia, geografia czy socjologia są bardziej przywiązane do paradygmatów stanowiących dorobek wymienionych dyscyplin, a jednocześnie częściej (niż przedstawiciele „młodszych” dyscyplin - np. nauk o kulturze fizycznej) czują się reprezentantami tych dyscyplin. Większość osób (47\%) z tytułem profesora deklarowała się jako przeciwnicy autonomizacji nauki o turystyce ( $44 \%$ pytanych profesorów było gotowych uznać nową dyscyplinę), podczas gdy reprezentanci pozostałych stopni naukowych w większości byli za autonomizacją nauki o turystyce. Podobnie przedstawiciele dyscyplin o krótszej tradycji naukowej byli bardziej skłonni uznać naukę o turystyce jako nową dyscyplinę. Z kolei pod względem długości okresu prowadzenia badań nad turystyką zauważono, że badacze z dłuższym doświadczeniem są bardziej ostrożni w przyjęciu nowej dyscypliny nauki. Paradoksalnie wśród respondentów, którzy zadeklarowali badania nad turystyką jako główną dziedzinę swoich zainteresowań badawczych było relatywnie więcej oponentów niż zwolenników autonomizacji nauki o turystyce (w stosunku do tych, którzy wskazali badania nad turystyką jako poboczny obszar ich aktywności zawodowej).

\subsection{Argumentacje respondentów}

Poza odpowiedziami na pytania zamknięte respondenci byli także proszeni o bardziej swobodne uzasadnienie swoich opinii dotyczących turystyki jako samodzielnej dyscypliny. Umożliwiło to poznanie argumentów leżących 
u podstaw poszczególnych stanowisk. Interesujące było także zestawienie tych argumentów z poglądami prezentowanymi w literaturze przedmiotu.

Argumenty najczęściej przytaczane przez zwolenników można podzielić na dwie grupy. Skupiały się one bowiem wokół aspektów metodologicznych lub wynikały z szeroko rozumianych uwarunkowań społecznych. W pierwszej grupie wskazywano głównie na specyfikę studiów nad turystyką, która wyróżnia je od innych dyscyplin, podkreślano wystarczającą ilość zgromadzonej wiedzy naukowej o turystyce, zauważono ryzyko zniekształcenia problemów badawczych, jeśli rozpatrywane one są tylko z perspektywy jednej szczegółowej dyscypliny, a także wskazywano na historyczną tendencję $\mathrm{w}$ rozwoju nauki przejawiającą się $\mathrm{w}$ wyodrębnianiu nowych dyscyplin. Druga grupa wymienianych argumentów związana była ze społeczną akceptacją studiów nad turystyką jako bardzo ważną dziedziną funkcjonowania współczesnych społeczeństw. Wielu respondentów wskazywało na te właśnie argumenty, uznając je za szczególnie istotne. W tym kontekście ankietowane osoby widziały poważny problem w braku dyscypliny naukowej mogącej stanowić instrumentarium ułatwiające zrozumienie specyficznych społecznych, gospodarczych, środowiskowych czy kulturowych problemów turystyki. Ponadto część respondentów wskazywała na liczne czasopisma naukowe, a także na programy akademickie jako na przejawy silnego społecznego zapotrzebowania na zrozumienie zjawisk i procesów turystycznych.

$\mathrm{Z}$ drugiej strony argumentacja oponentów uznania turystyki jako samodzielnej dyscypliny koncentrowała się przede wszystkim na przesłankach natury metodologicznej. Przytaczali oni głównie te same argumenty, które przedstawiono $\mathrm{w}$ omówieniu literatury przedmiotu, $\mathrm{w}$ tym przede wszystkim: brak oryginalnych teorii wyjaśniających zjawiska turystyczne, a także brak powszechnie akceptowanej definicji oraz specyficznych metod. Podkreślano również niemożność ustalenia wspólnego paradygmatu, na którym nowa dyscyplina mogłaby być oparta. Pojawiły się także poglądy, że turystyka może stanowić co najwyżej przedmiot badań, nie zaś samodzielną dyscyplinę. Część badaczy uznała, że obecna sytuacja jest satysfakcjonująca, ponieważ istniejące dyscypliny są wystarczająco dobrymi narzędziami badawczymi.

Być może najbardziej interesującym wnioskiem płynącym $\mathrm{z}$ analizy jakościowej było wskazanie na ten sam argument zarówno przez zwolenników, jak i przeciwników autonomizacji naukowej turystyki. Jedni i drudzy podkreślali bowiem interdyscyplinarność studiów nad turystyką jako na czynnik uzasadniający ich stanowisko. Przy czym przeciwnicy podkreślali 
fakt, że turystyka jest genetycznie tak zróżnicowana, a jej cząstkowe pola badawcze przynależą do innych dyscyplin, że tylko podejście interdyscyplinarne może przynieść postęp metodologiczny. Z kolei zwolennicy dyscyplinarności turystyki, wychodząc $z$ tego samego stwierdzenia o nieheterogeniczności przedmiotu badań turystyki, zauważali, że za pomocą nowej dyscypliny można by lepiej zrozumieć istotę zjawiska, jakim jest turystyka.

\subsection{Analiza regionalna}

Analizy regionalne zostały przeprowadzone w celu ustalenia specyfiki poglądów prezentowanych przez badaczy wywodzących się z różnych części świata (często także z różnych tradycji badawczych). Wyróżniono w tym celu następujące regiony: Europa, Ameryka Północna i Południowa (jako jeden region), Azja, Australia i Oceania (AAiO). Podział ten uzupełniono o grupę polskich badaczy, co umożliwiło porównanie ich poglądów z opiniami światowymi (rys. 1).

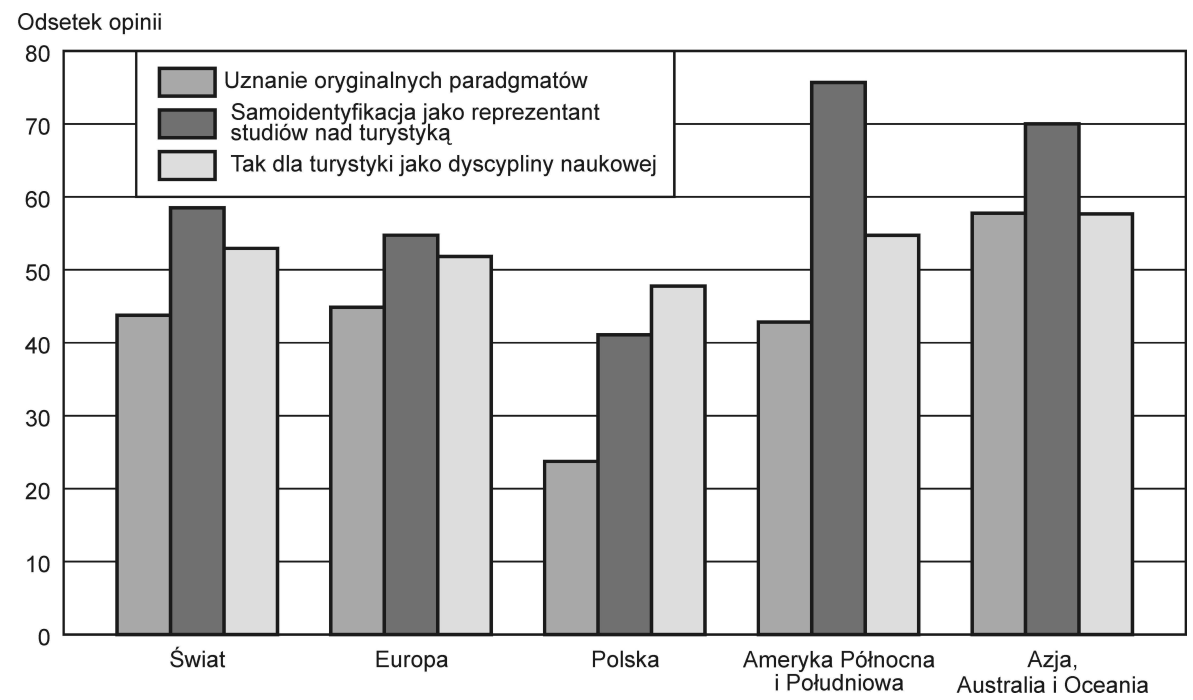

Rys. 1. Autonomizacja nauki o turystyce w opiniach badaczy reprezentujących różne regiony świata Źródło: opracowanie własne

Europa. Próba objęła 126 respondentów z prawie wszystkich krajów naszego kontynentu (wraz z Gruzją, Rosją i Turcją, ale bez Polski, która została omówiona oddzielnie). Opinie wyrażone przez badaczy europejskich w od- 
niesieniu do "średniej” światowej oraz do poglądów pochodzących z poszczególnych regionów wydają się być raczej konserwatywne. Zanotowano $\mathrm{u}$ nich bowiem relatywnie najniższy (poza Polską) poziom akceptacji dla autonomizacji turystyki jako nauki (52\%); stosunkowo niskie były także poziomy uznania paradygmatów "turystycznych" oraz samoidentyfikacji jako przedstawicieli studiów nad turystyką (odpowiednio 45 i 55\%).

Ameryka Północna i Południowa. Analiza objęła odpowiedzi 23 badaczy pracujących w amerykańskich uniwersytetach, z czego 19 pochodziło z USA i Kanady. Wyniki wskazują na znaczące wewnętrzne zróżnicowanie poglądów, a czasami także na ich pewną niekonsekwencję. Większość respondentów $(76 \%)$ uważała siebie jako reprezentantów badań nad turystyką, ale tylko $43 \%$ zadeklarowało, że w swoich badaniach opiera się na oryginalnych paradygmatach uznanych dla tej dziedziny. Akceptacja dla autonomizacji nauki o turystyce wśród badaczy z tego regionu była na średnim poziomie $55 \%$.

Azja, Australia i Oceania. Próba objęła 19 respondentów (12 z krajów azjatyckich oraz $7 \mathrm{z}$ Australii i Nowej Zelandii). Ankietowani badacze z tego regionu $\mathrm{w}$ największym stopniu byli skłonni uznać autonomię turystyki jako nauki. Aż 58\% wśród nich wyraziło taką opinię. Tyle samo uważało, że istnieją specyficzne paradygmaty „turystyczne”, zaś 70\% respondentów czuło się reprezentantami studiów nad turystyką. Warto też zauważyć, że opinie badaczy $\mathrm{z}$ tego regionu były $\mathrm{w}$ największym stopniu spójne i stały $\mathrm{w}$ dość wyraźnej opozycji do poglądów europejskich, a także średniej światowej.

Polska. Próba polska liczyła 89 respondentów z różnymi stopniami naukowymi (lub tytułami naukowymi, ew. zawodowymi), a także różne doświadczenie oraz wiek. Reprezentowali oni wszystkie ważniejsze ośrodki naukowe zajmujące się turystyką. Wyniki tych badań (BUTOWSKI 2014a, 2014b) dały podstawę do sformułowania następujących wniosków: 1) tylko $24 \%$ respondentów zadeklarowało, że korzysta w swoich badaniach z oryginalnych paradygmatów "turystycznych"; 2) jednocześnie $41 \%$ wśród nich uważało siebie za reprezentantów badań nad turystyką; 3) zaś $48 \%$ ankietowanych osób było gotowych uznać turystykę za dyscyplinę naukową. Dane te wskazują na dość dużą niekonsekwencję w zakresie oceny sytuacji metodologicznej badań nad turystyką (a także ich statusu formalnego) w Polsce. $\mathrm{Z}$ jednej strony respondenci na relatywnie wysokim poziomie są gotowi uznać autonomizację nauki o turystyce, z drugiej zaś strony wydają się być mocno przywiązani do paradygmatów uznawanych przez inne dyscypliny. Na poziomie ogólnym opinie polskich badaczy, w porównaniu z przedsta- 
wicielami innych regionów, a także $\mathrm{w}$ odniesieniu do średnich światowych, jawią się jako najbardziej konserwatywne (wszystkie szczegółowe wskaźniki notują najniższe poziomy).

\section{Wnioski końcowe}

Badając zagadnienie nauki o turystyce jako samodzielnej dyscypliny należy wziąć pod uwagę wiele różnych, często wykluczających się nawzajem grup poglądów, które w skróconej formie zostały przedstawione we wprowadzającej części niniejszego opracowania. Z drugiej strony wydaje się, że problem autonomizacji nauki o turystyce powinien być rozpatrywany w szerszym kontekście naukowej tożsamości badaczy zajmujących się turystyką. Wynika to $\mathrm{z}$ faktu, że na opinie wyrażane przez poszczególne grupy naukowców zasadniczy wpływ mają różne tradycje badawcze, z których się oni wywodzą. W celu rzeczywistego ustalenia znaczenia tych czynników przeprowadzono badania empiryczne. W rezultacie umożliwiło to przedstawienie propozycji rozwoju metodologicznego badań nad turystyką.

Jak wcześniej wspomniano, wielu przeciwników autonomizacji turystyki jako nauki opiera się na metodologicznych przesłankach. Przy czym odnoszą się oni często do paradygmatycznego modelu rozwoju nauki T. Kuhna, w którym wyróżniono tzw. okres przedparadygmatyczny rozwoju dyscyplin naukowych oraz fazę ukształtowanego paradygmatu. Oponenci autonomizacji nauki o turystyce twierdzą, że badania nad tą dziedziną pozostają $\mathrm{w}$ stadium przedparadygmatycznym i z powodu nieprzystawalności paradygmatów, z których korzystają, nie mają szans na przejście do fazy ukształtowanego paradygmatu.

Wydaje się jednak, że argumentacja taka może być poddana krytyce z kilku pozycji. Po pierwsze model Kuhna został opracowany głównie na podstawie obserwacji rozwoju nauk przyrodniczych (i nie w całości przystaje on do nauk społecznych i humanistycznych). Świadczą o tym podobne problemy z uznaniem w przeszłości ",nowych” na tamte czasy dyscyplin, takich jak: etnografia, antropologia kulturowa, a jeszcze wcześniej nawet socjologia. Wszystkie one były krytykowane jako „nienaukowe” z metodologicznych pozycji nauk przyrodniczych. Co więcej, paradoksalnie, wydaje się, że największym oponentem takiego stosowania swojego modelu był sam T. Kuhn (OKASHA 2002). Zakwestionował on bowiem dominującą rolę logicznych pozytywistów w metodologii nauki oraz poddał krytyce Poppe- 
rowską wizję nauki. Zarzucił on im skupienie się na tzw. kontekście uzasadnienia naukowego (context of justification) i zupełne zaniedbanie w procesie rozwoju nauki tzw. społecznego kontekstu odkrycia (context of discovery). Autor ten uznał, że to właśnie kontekst odkrycia, rozumiany jako wpływ szeroko rozumianych uwarunkowań społecznych (historycznych, kulturowych, ekonomicznych), w największym stopniu decyduje o rozwoju nauki. W tym świetle argumenty na rzecz autonomizacji nauki o turystyce polegające na społecznym zapotrzebowaniu na wiedzę z zakresu tej dziedziny, zyskują solidne podstawy w teorii rozwoju nauki.

W powyższym kontekście można więc postawić inne, dość zasadnicze pytanie: kto może decydować o uznaniu turystyki jako dyscypliny naukowej? Wyniki badań empirycznych, a także inne analizy (TOPALOGLU 2014) pokazują, że przynajmniej na poziomie instytucjonalnym turystyka jako nauka została uznana w niektórych krajach. Jednocześnie należy zauważyć, że w większości państw nie posiada ona takiego statusu (HANDSZUH 2014, RATZ 2014). Próbą odpowiedzi na powyższe pytanie niech będzie teza zakładająca, że nikt nie ma prawa w sposób autorytarny narzucać swoich poglądów w powyższym zakresie, a decyzja powinna zależeć jedynie od lokalnej społeczności badaczy. Pogląd taki opiera się oczywiście na teoretycznych przesłankach nieklasycznej socjologii nauki i jest zakorzeniony w poglądach Kuhna na temat kontekstu odkrycia naukowego. Wydaje się, że w stosunku do nauk społecznych i humanistycznych (w przeciwieństwie do nauk przyrodniczych) podejście takie jest wystarczająco uzasadnione. Co więcej, hipoteza ta została także pozytywnie zweryfikowana $\mathrm{w}$ przeprowadzonych badaniach empirycznych, których wyniki były zróżnicowane między poszczególnymi regionami.

Przy decydowaniu o uznaniu lub nie nauki o turystyce jako samodzielnej dyscypliny warto wziąć także pod uwagę praktyczne konsekwencje takiej decyzji. Niewątpliwie legitymacja akademicka oraz naukowe uznanie dla turystyki mogą ułatwić finansowanie badań z tej dziedziny (HALL 2004, S. 147, RÁTZ 2014), o czym świadczą także opinie wyrażane przez respondentów w badaniach ankietowych.

Trzeba w tym miejscu także odnieść się do obaw artykułowanych przez J. Tribe'a i innych autorów na temat "tyranizującej roli”, jaką może odgrywać nowa dyscyplina poprzez ograniczenie wolności badań nad turystyką. Pogląd taki na pierwszy rzut oka wydaje się być dość przekonujący, ale po bliższym jego przeanalizowaniu pojawia się kilka istotnych wątpliwości dotyczących jego słuszności. Warto w tym miejscu jeszcze raz odnieść się do 
doświadczeń innych nauk społecznych i humanistycznych, które podobnie jak hipotetyczna nauka o turystyce mają podobne "słabości” metodologiczne. Nie słychać jednak głosów narzekania z tamtych środowisk na ograniczenia, jakie narzucają im ramy instytucjonalne dyscyplin. Przeciwnie rozwój i uznanie nowych dyscyplin podnosi prestiż akademicki ich reprezentantów.

Pozostaje wreszcie odnieść się do problemu inter-, cross- i transdyscyplinarności $w$ badaniach nad turystyką. Nie ulega wątpliwości, że podejścia takie są niezbędne do rozwiązywania złożonych zjawisk i procesów turystycznych. Z drugiej strony wydaje się, że aby rozwijać postmodernistyczną metodologię w badaniu turystyki, wcześniej należy stworzyć solidne podstawy ontologiczne i metodologiczne zapewniające przynajmniej minimum „rzetelności” naukowej (RÁTz 2014). W tym kontekście propozycja ujęcia badań nad turystyką $w$ ramy dyscypliny wydaje się być rozsądnym rozwiązaniem. Powinna ona bowiem zapewnić bezpieczne przejście do etapu badań postdyscyplinarnych. W przeciwnym razie jest niebezpieczeństwo, że będą one prowadzone na metodologicznych „ruchomych piaskach”.

Przedstawione powyżej rozważania dostarczają argumentów na rzecz autonomizacji nauki o turystyce. Nie oznacza to jednak, że przed zwolennikami nauki o turystyce nie stoją żadne przeszkody. Po pierwsze, przyjmując perspektywę czysto poznawczą, należy bardzo krytycznie zastanowić się nad tym, czy dysponując samodzielną dyscypliną będziemy w stanie lepiej poznawać i rozumieć turystykę w całej rozciągłości jej zjawisk i procesów? Czy może w większym stopniu poznanie takie zapewniają dotychczasowe nauki zajmujące się turystyką z własnych pozycji? Biorąc pod uwagę tak szerokie pole badawcze (oraz przedmiot) turystyki odpowiedź pozostaje bardzo wątpliwa. W tym kontekście propozycje J.M. Hoernera i Z. Jovicicia, dotyczące nauki o turystyce jako dyscyplinie syntezującej dotychczasową wiedzę, wydają się być mało realistyczne. Być może bardziej realnym rozwiązaniem byłoby skupienie się na tych cechach, które odróżniają turystykę od innych aktywności człowieka (stanowiąc tym samym jej tzw. cechy konstytutywne). Zawęziłoby to prawdopodobnie jej przedmiot badań, a tym samym umożliwiło skupienie się na aspektach, których badanie nie jest możliwe z perspektywy innych dyscyplin. O możliwości takiej wspominają Z. CHOJNICKI (2005) i R. MACIOŁEK (2002).

Podsumowując powyższą dyskusję i odnosząc ją do głównego problemu badawczego dotyczącego instrumentarium metodologicznego pomocnego w lepszym poznaniu turystyki, można by postawić tezę, że uda się to osiąg- 
nąć, kiedy badania nad turystyką będą prowadzone zarówno w ramach istniejących dyscyplin, jak również poprzez nową dyscyplinę - naukę(i) o turystyce. Przy czym, co bardzo ważne, jej przedmiot powinien obejmować raczej te specyficzne cechy turystyki, które wyróżniają ją od wszystkich społeczno-kulturowych, gospodarczych i przestrzenno-środowiskowych uwarunkowań.

\section{Bibliografia}

AIREY D., 2008, Tourism education life begins at 40, Téoros, 27(1), s. 27-32.

ARONOWITZ S. GIROUX H., 1991, Postmodern education: politics, culture and social criticism, University of Minnesota Press, Minneapolis.

AteljeVIC I., PRITCHARD A., MORGAN N., 2007, The critical turn in tourism studies: innovative research methodologies, Elsevier, Amsterdam.

ATHIYAMAN A., 1997, Knowledge development in tourism: Tourism demand research, "Tourism Management", 18(4), s. 221-228.

BABU S.S., 2008, Tourism as disciplines and industry. Some comments on the progressing debates, [w:] S.S. Babu, S. Mishra, B.B. Parida (red.), Tourism Development Revisited. Concepts, Issues and Paradigms, SAGE, s. 33-53.

BARNETT R., 1990, The idea of higher education. Buckingham: The Society for Research into Higher Education, Open University Press.

BARNETT R., 1997, Higher education, a critical business. Buckingham: The Society for Research into Higher Education, Open University Press.

BERNSTEIN R., 1991, Beyond objectivism and relativism: Science, hermeneutics, and praxis, University of Pennsylvania Press, Philadelphia.

BORRET A., 2005, Discipline d'enseignement, sujet d'études, „Revue Espaces”, 223, s. 18-20.

BOWEDES T., 1982, Development of advanced tourism studies in Holland, "Annals of Tourism Research", 9, s. 35-51.

BUTOWSKI L., 2011, Tourism - an academic discipline (discursive article), „Turyzm”, 21, 1-2, s. 17-24.

BUTOWSKI L., 2014a, The phenomenology of tourism: in search of the essence of the phenomenon. Towards new paradigms for tourism research, [w:] F. Dias, J. Kosmaczewska, E. Dziedzic, A. Mogliulo (red.), Tourism Research in a Changing World, GITUR - Tourism Research Group of Polytechnic Institute of Leiria, s. 250-265.

BUTOWSKI L., 2014b, The ontological and epistemological foundations of tourism research. Scientific identity of Polish scholars of tourism, „Economics Problems of Tourism”, 4(28), s. 61-76.

BUTOWSKI L. (red.), 2014c, Searching for the scientific identity of tourism research, Warsaw School of Tourism and Hospitality Management, Warszawa.

CAZES G., 2001, À propos de tourismologie. La science par autoproclamation, „Revue Espaces”, 187, s. 46-53.

CERIANI-SEBREGONDI G., CHAPUIS A., GAY J-C., KNAFOU R., STOCK M., VIOLIER P., 2008, Quelle serait l'objet d'une 'science du tourisme' ?, „Téoros", 27(1), s. 7-13.

CHŁOPECKI J., 2005, Turystologia jako dyscyplina naukowa, [w:] R. Winiarski, W. Alejziak (red.), Turystyka w badaniach naukowych, s. 263-274. AWF, WSIiZ, Kraków-Rzeszów.

CHOJNICKI Z., 2005, Charakter $i$ sytuacja nauki o turystyce - rozważania metodologiczne, Zeszyty Naukowe Wyższej Szkoły Gospodarki, Turystyka i Rekreacja, 3, s. 11-23.

COHEN E., 1979, Rethinking the sociology of tourism, „Annals of Tourism Research”, Jan.-Mar., s. 110-111. 
Coles T., Hall M., Duvall D., 2005, Mobilising tourism: A Post-Disciplinary Critique, „Tourism Recreation Research", 30(2), s. 31-42.

COMIC D., 1989, Tourism as a Subject of Philosophical Reflection, „Revue de Tourisme”, 44, s. 6-13.

CUFFY V., TRIBE J., AIREY D., 2012, Lifelong Learning for Tourism, „Annals of Tourism Research”, 39(3), s. $1402-1424$.

DANN G., NASH D., PEARCE P., 1988, Methodology in Tourism Research, "Annals of Tourism Research", 18, s. 155-169.

DARBELlAy F., STOCK M., 2012, Tourism as Complex interdisciplinary Research Object, "Annals of Tourism Research", 39(1), s. 441-458.

Devailly J.M., 2006, Géographie du tourisme. Pérégrinité ou chaos ?, 'Harmattan, Paris.

DeWAILly J.M., 2008, Complexité touristique et approche transdisciplinaire du tourisme, „Téoros”, 27(1), s. 22-26.

ECHTNER C.M., JAMAL T.B., 1997, The Disciplinary Dilemma of Tourism Studies, „Annals of Tourism Research", 24, s. 868-883.

FRANKLIN A., CRANG M., 2001, The trouble with tourism and travel industry, „,Tourist Studies", 1(1), s. 22.

Goeldner C.R., Ritchie, J.R.B., 2006, Tourism: Principles, Practices, Philosophes, John Wiley \& Sons, Hoboken.

HALL M., 2004, Reflexivity and tourism research, [w:] J. Phillimore \& L. Godson (red.), Qualitative Research in Tourism, Routledge, London, s. 137-155.

HALL M., Williams A., LEW A., 2004, Tourism: Conceptualisations, Institutions and Issues, [w:] A. Lew, M. Hall, A. Williams (red.), A Companion to Tourism, s. 3-21, Blackwell, Oxford

HANDSZUH H., 2014, The Place of Tourism in the Scientific System of Spain (an Outline), [w:] L. Butowski (red.), Searching for the scientific identity of tourism research, Warsaw School of Tourism and Hospitality Management, Warszawa, s. 17-33.

HiLlali M., 2008, La science du tourisme dans le discours des acteures internationaux : débat ou polémique ?, „Téoros", 27(1), s. 42-50.

HOERNER J.M., 2000, Pour la reconnaissance d'une science touristique, „Revue Espaces”, 173, s. 18-20.

HOERNER J.M., 2002, Pour une novelle définition du tourisme, „Revue Espaces”, 224, s. 15-20.

HOERNER J.M., 2008, Contrubution à la science du tourisme, „Téoros”, 27(1), http://teoros.revues. org/355; 23.10.2014.

HOERNER J.M., SICART C., 2003, La science du tourisme, Balzac Editeur, Baixas.

JAFARI J., 1990, Research and scholarship: The basis of toursm education, "Journal of Tourism Studies", 1, s. 33-41.

JAFARI J., 2001, The Scientification of Tourism, [w:] V.L. Smith, M.A. Brent (red.), Hosts and Guests Revisited: Tourism Issues in the 21 $1^{\text {st }}$ Century, s. 28-41.

JOVICIC Z., 1988, A Plea for Tourismological Theory and Methodology, , Revue de Tourisme”, 43, s. 2-5.

KADRI B., 2008, La question du statut scientifique du tourisme: présentation, „Téoros”, 27(1), http:// teoros.revues.org/345; 23.10.2014.

KNAFOU R., 2005, La recherche en tourisme s'organise, „Revue Espaces”, 225, s. 11-14.

KUHN T.S., 1996 (3rd ed.), The Structure of Scientific Revolutions, University of Chicago, Chicago.

LEIPER N., 1981, Towards a cohesive curriculum tourism: The case for a distinct discipline, "Annals of Tourism Research", 8(1), s. 69-84.

LEIPER N., 1990, Tourism Systems: An interdyscyplinary Study, Occasion Papers, 2. Massey University.

LEIPER N., 2000, An Emerging Discipline, „Annals of Tourism Research”, 27, s. 805-809.

LISZEWSKI S., 2010, Nauka czy nauki o turystyce, „Turyzm”, 20, 2, s. 37-45.

LYNCH P., BROWN R., 1999, Utility of Large-scale Leisure Research Agendas, „Managing Leisure”, 7(4), s. 63-77.

MACIOŁEK R., 2002, Osobliwości metodologiczne badań nad turystyka, Zeszyty Naukowe Wyższej Szkoły Turystyki i Hotelarstwa w Bydgoszczy, 2, s. 17-26. 
MATTHEWS H., RichTER L., 2001, Political science and tourism, "Annals of Tourism Research", 18, s. 120-135.

MAZURKIEWICZ L., 2005, Czy istnieje teoria Turystyki, „Problemy Turystyki”, 3/4, s. 155-167.

MAZURKIEWICZ L., 2012, Wybrane teorie oraz metody badawcze turystyki, Studia i Monografie AWF, Warszawa.

MeETHAN K., 2001, Tourism in Global Society: Place, Culture and Consumption, Palgrave, New York.

OKASHA S. 2002, Philosophy of Science. A Very Short introduction, Oxford University Press.

PAGE S.J., 2003, Evaluating Research Performance in Tourism: The UK Experience, „Tourism Management", 24(4), s. 607-622.

PEARCE P.L., 1993, Defining Tourism Study as a Specialism: A Justification and Implications, „Teoros International", 1, s. 25-32.

PEARCE P.L., BUTLER R. (red.), 1993, Tourism Research: Critiques and Challenges, Routledge, London.

RÁTZ T., 2014, Crossdisciplinarity or tourismology? The scientific identity of tourism in Hungary, [w:] L. Butowski (red.), Searching for the scientific identity of tourism research, Warsaw School of Tourism and Hospitality Management, Warszawa, s. 35-57.

RITCHIE J.R.B, SHEEHAN L.R., TIMUR S., 2008, Tourism Sciences or Tourism Studies? Implications for the Design and Content of Tourism Programming, "Téoros. Revue de Recherche en Tourisme”, 27, 1, s. 33-41.

ROGOZIŃSKI K., 1985, Tourism as a Subject of Research and integration of Sciences, „Problemy Turystyki", 4, s. 7-19.

ROJEK C., URRY J., 1997, Touring cultures, Routledge, London.

RYAN C., 1997, Tourism a mature subject discipline?, „Pacific Tourism Review”, 1(1), s. 3-5.

RYAN C., 2001, Academia - industry tourism research links: states of confusion, „Pacific Tourism Review”, 5(3/4), s. 83-96.

SQUIRE S., 1994, Accounting for Cultural Meanings. The interface between geography and tourism studies, „Progress in Human Geography”, 18, s. 1-16.

STAFFORD J., 1985, Le paradigm culturaliste en téorologie : étude, analyse et critique, „Téoros”, 7(1), s. 5-8.

STAFFORD J., 1992, Connaissances en tourisme et reconnaissance sociale, „Téoros", 11(1), s. 44-46.

SZUBERT-ZARZECZNY U., 2001, Kilka uwag o potrzebie autonomizacji "nauki o turystyce", Zeszyty Naukowe AWF w Krakowie, 81, s. 75-79.

TAILLON J., 2014, Understanding tourism as an academic community, study, or discipline, "Journal of Tourism \& Hospitality", 3(3), s. 131-136.

TOPAlOglu C., 2014, Tourism Education in Turkey and the Place of Tourism within the Science System, [w:] L. Butowski (red.).), Searching for the scientific identity of tourism research, Warsaw School of Tourism and Hospitality Management, Warszawa, s. 59-71.

TRIBE J., 1997, The indiscipline of Tourism, „Annals of Tourism Research”, 24, s. 638-654.

TRIBE J., 2003, The RAE-ification of tourism research in the UK, "International Journal of Tourism Research", 5, s. 225-234.

TRIBE J., 2006, The truth about tourism, „Annals of Tourism Research”, 33(2), s. 360-381.

TRIBE J., 2010, Tribes, territories and networks in the tourism community, "Annals of Tourism Research", 37(1), s. 7-33.

VICÉRIAT P., ORIGET DU CLUZEAU C., BALFET M., 2005, Ensemble pour la reconnaissance d'une science du tourisme, „Revue Espaces”, 224, s. 14-15.

WEILER B., 2003, Tourism Research and Theories: A Review, [w:] A. Lockhood, S. Medlik (red.), Tourism and Hospitality Industry in the 21st Century, Butterworth-Heinemann, London, s. 82-93.

WITT S., BROKE M., BUCKLEY P., 1991, The management of international tourism, Unwin Hyman, London. 